\section{Analysis of the sanitary survey 2015-2017 conducted in the gulf of La Spezia (Italy): Reclassification of the areas of production of live bivalve molluscs}

\author{
Alice Giusti, ${ }^{1}$ Erica Costa, ${ }^{2}$ \\ Alice Traina, ${ }^{1}$ Daniele Nucera, ${ }^{3}$ \\ Patrizia Serratore, ${ }^{4}$ Mino Orlandi, ${ }^{2}$ \\ Andrea Armani ${ }^{1}$
}

${ }^{1}$ FishLab, Department of Veterinary Sciences, University of Pisa; ${ }^{2}$ Liguria Local Health Unit - ASL 5, Complex Unit of Hygiene of Foods and Animal Origin, La Spezia; ${ }^{3}$ Department of Agriculture, Forest and Food Science, University of Turin; ${ }^{4}$ Department of Veterinary Medical Sciences, University of Bologna, Italy

\begin{abstract}
The sanitary survey is aimed at classifying and monitoring the production areas of live bivalve molluscs (LBM) and it is performed using standards that are provided by the Centre for Environment, Fisheries and Aquaculture Science's Guide to Good Practice. In this study, data from the sanitary survey carried out by the As15 Spezzino on the production areas of the gulf of $\mathrm{La}$ Spezia during the period 2015-2017 were analysed. The number and type of the analysis performed both on the total sampling and on the individual target species, as well as the number and type of found non-compliance (assessed on both mandatory parameters and on parameters fixed by the local monitoring plan) were considered. Data were also compared with those from the sanitary survey 2012-2014. Appropriate statistic tests were used to evaluate data from E. coli and Norovirus monitoring. Overall, 4306 analysis were performed, especially on the species $M$. galloprovincialis $(89 \%)$ and they were mostly focused on to the search of biological agents. 160 $\mathrm{NC}$ were detected. Most of the NC concerns the Norovirus's positivity $(93.75 \%)$ in $M$. galloprovincialis and C. gigas. A correlation between the levels of $E$. coli and rainfall/seasonality (higher levels in the colder months) was proved, especially in the sampling points located in the inner part of the dam and in the Portovenere Bay. Class B was reconfirmed for $M$. galloprovincialis, the production areas of $C$. gigas were reclassified as A and those of $V$. verrucosa were definitively closed. The sanitary sur-
\end{abstract}

vey was therefore confirmed as a useful tool for reclassification and for monitoring LBM production areas.

\section{Introduction}

Foodborne zoonoses associated with the consumption of bivalve molluscs are reported worldwide. Contamination occurs because they are suspension feeders that filter and concentrate small particles of plankton and the contaminant substances associated with them such as pathogenic bacteria, viruses algal biotoxins and chemicals (EFSA, 2015). The health risk is especially related to the consumption of raw or insufficiently cooked bivalve molluscs harvested in areas that are impacted by contaminants carried by domestic wastewater, waters for agricultural activities, run-off waters during heavy rains, presence of waterways, etc. (Potasman et al., 2002).

As established by EU legislation, gatherers may only harvest LBM from production areas with fixed locations and boundaries that the Competent Authority (CA) has classified as being of class A, B or C using Escherichia coli as indicator organism of faecal contamination (Regulation EC $\mathrm{n}$. 853/2004; Regulation EC n. 854/2004). In the Annex II of the Regulation (EC) $n$. $854 / 2004$ it is especially mentioned that, in order to classify a production area, the CA implements a sanitary survey aimed at: 1) evaluating the sources of contamination in the catchment area and the quantities of organic pollutants during the different periods of the year (mainly related to seasonal variations of humans and animals population, rainfall readings, waste-water treatment, etc.), 2) determining the characteristics of the circulation of pollutants (considering the current patterns, the bathymetry and the tidal cycle) and 3) establishing a representative LBM sampling program for the considered area. In addition to E. coli, other mandatory parameters (MPs) mentioned by the EU laws should be evaluated during the sanitary surveys implementation, such as Salmonella spp. and marine biotoxins, whose limits are fixed by the Commission Regulation (EC) n. 2073/2005 and the Regulation (EC) n. 853/2004, respectively, or certain chemical contaminants whose limits are defined by the Commission Regulation (EC) n. 1881/2006. Also, the Council Regulation (EC) n. $733 / 2008$, that was issued in response to the Chernobyl nuclear power station accident in 1986, fixed the accumulated maximum radioactive level in terms of caesium-134 and -137. In addition, other biological, physical and chemical non-mandatory parameters (nMPs) can be used by CA as an
Correspondence: Erica Costa, Sistema Sanitario Regione Liguria - Azienda Sociosanitaria Ligure 5, Struttura Complessa Igiene degli Alimenti di Origine Animale Via Fiume 13719122 La Spezia, Italia. Tel.: +39.0187.534573

E-mail: erica.costa@asl5.liguria.it

Key words: Bivalves, sanitary survey, official control, health risk.

Contributions: The authors contributed equally.

Conflict of interests: The authors declare no potential conflict of interests.

Funding: None.

Availability of data and materials: The data that support the findings of this study are available from the corresponding author upon reasonable request.

Ethics approval and consent to participate: This research was conducted in accordance with all relevant guidelines and procedures.

Consent for publication: The manuscript does not contain any individual person's data in any form.

Received for publication: 26 July 2019 Accepted for publication: 18 Deceber 2019.

This work is licensed under a Creative Commons Attribution-NonCommercial 4.0 International License (CC BY-NC 4.0).

(C) Copyright: the Author(s), 2020

Licensee PAGEPress, Italy

Italian Journal of Food Safety 2020; 9:8448

doi:10.4081/ijfs.2020.8448

additional control to improve risk management in production areas.

The Centre for Environment Fisheries and Aquaculture Science (CEFAS) published an updated Community guide providing principles and operational guidelines (e.g. sampling criteria, microbiological tests methods and procedures for interpreting the tests results) that should be applied by the CA to carry out the sanitary survey (CEFAS, 2017). Ongoing monitoring (generally of a three-annual basis) are also needed to determine whether the level of risk has changed, and the classification status should be therefore modified. Compulsorily, a report on the results at the end of the threeyear period analysis should be published.

Despite of this legislative background, a series of audits undertaken on eleven Member States between 2011 and 2013 by the European Commission's Food and Veterinary Office (FVO) highlighted consistent gaps in the classification systems of 
LBM production areas (European Commission's Food and Veterinary Office, 2014).

Given the necessity to fulfil EU requirements, the Liguria Region implemented its first sanitary survey on the production areas of the gulf of La Spezia, which have been identified in 1996 with the Resolution n. 2216 of the Liguria Regional Executive. Mussels (Mytilus galloprovincialis) and oysters (Crassostrea gigas), as well as two natural beds of marine truffle (Venus verru$\cos a$ ), were harvested in such areas. The survey covered the three years 2012-2014 and the relative outcomes were reported in a final report published in 2015 (SS-2015) (Sanitary Survey, 2015). At the end of this process, all the production areas were classified as B. The procedures for the survey concerning the subsequent three-year period were initiated in 2015 and the relative final report was published in 2018 (SS2018) (Sanitary Survey, 2018).

The aim of this study was to analyse the data from the SS-2018 in order to provide a detailed overview of the analysis that have been performed and to highlight the major non-compliances that have been found during the related three-years period (20152017). Moreover, the sanitary status of the production areas of the gulf of La Spezia respect to the previous three-years period (2012-2014) were analysed, through the comparison with the SS-2015, to assess any variations

\section{Materials and Methods}

\section{SS-2018 analysis}

All the data extrapolated from the SS2018 referred to the outcomes of the official analysis that were performed by the CA within the LBM production areas of the gulf of La Spezia during the three-year period 2015-2017. The points that were identified in the sanitary survey of the previous threeyears period were used for the sampling of M. galloprovincialis (seven sampling points), V. verrucosa (two sampling points) and $C$. gigas (one sampling point). To facilitate the understanding, the LBM production areas and sampling points provided by SS-2018, were reported in Figure 1. The survey was based on the annual LBM monitoring plan (Asl 5 Spezzino, 2018). The following data were especially considered both on the three species overall and on separated data: i) number and type of analysis performed in the sampling points for the three examined species ii) number and type of found non-compliances (NC), related to both mandatory parameters (MPs) and addi- tional non-mandatory parameters (nMPs) (Table 1). Finally, the sanitary status of the production areas was compared to that from SS-2015.

\section{Statistical analysis}

The following statistical analysis was conducted on data from the three-year period 2015-2017: 1) chi-squared test was applied on prevalence data of Norovirus for comparing sampling points (Figure 1) divided into three groups, "inside the dam" (grouping EI; WI; CI), "outside the dam" (grouping EE; WE) and "Portovenere Bay/Palmaria Isle Bay" (grouping PB; PALM); 2) The seasonality impact on $E$. coli MPN was evaluated by grouping the months of the year in two periods (from April to October and from November to March) and statistical differences between the two groups were evaluated by means of Mann Whitney $U$ test on both the MPN overall (without considering the different sampling sites) and separated data (for each sampling point, independently). Moreover, the $E$. coli MPN was related to the rainfall that was measured both at 4 and 7 days before the sampling by using Spearman's rho coefficient. This latter analysis was performed both for each sampling point and by grouping them as explained for the chi-

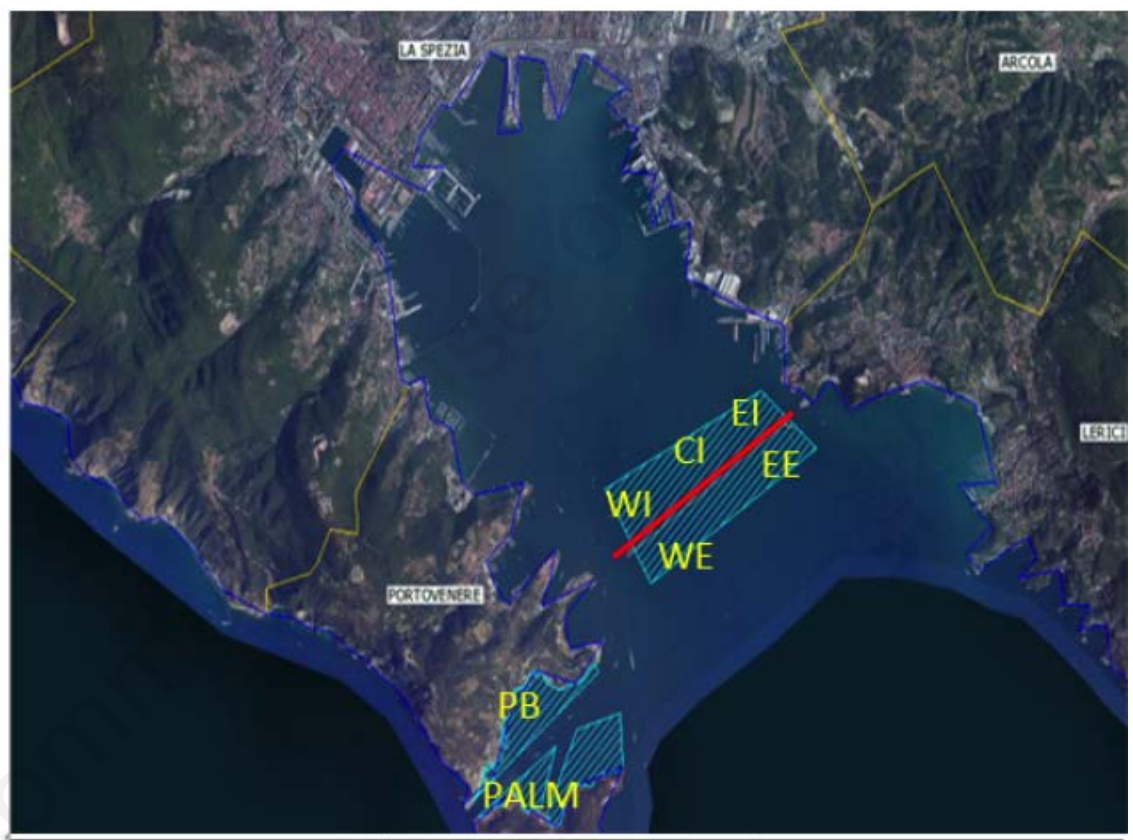

\begin{tabular}{|c|c|c|}
\hline Production Area & $\begin{array}{c}\text { Sampling point } \\
\text { (geographical coordinates } \\
\text { Lat/Long) }\end{array}$ & Species \\
\hline \multirow{2}{*}{ PB } & $44.057892 \mathrm{~N} / 9.943861 \mathrm{E}$ & $\begin{array}{c}\text { Mbotilus galloprovincialis } \\
\text { (1) }\end{array}$ \\
\hline & $44.057372 \mathrm{~N} / 9.842303 \mathrm{E}$ & Venus verrucosa $(1)$ \\
\hline \multirow[t]{2}{*}{ PALM } & $44.050794 \mathrm{~N} / 9.850206 \mathrm{E}$ & $\begin{array}{c}\text { Matilus galloproxincialis } \\
\text { (2) }\end{array}$ \\
\hline & $44.04898 \mathrm{~N} / 9.84175 \mathrm{E}$ & Venus verrucosa $(2)$ \\
\hline EI & $44.078431 \mathrm{~N} / 9.871744 \mathrm{E}$ & $\begin{array}{l}\text { Mytilus galloproyincialis } \\
\text { (3) and Crassostrea gigas } \\
\text { (1) }\end{array}$ \\
\hline WI & $44.072528 \mathrm{~N} / 9.858883 \mathrm{E}$ & $\begin{array}{c}\text { Motilus galloproxincialis } \\
\text { (4) }\end{array}$ \\
\hline $\mathrm{CI}$ & $44.075725 \mathrm{~N} / 9.865947 \mathrm{E}$ & $\begin{array}{l}\text { Sortilus galloproxincialis } \\
\text { (5) }\end{array}$ \\
\hline $\mathrm{EE}$ & $44.077233 \mathrm{~N} / 9.880128 \mathrm{E}$ & $\begin{array}{l}\text { Moxtilus galloproxincialis } \\
\text { (6) }\end{array}$ \\
\hline WE & $44.070111 \mathrm{~N} / 9.862522 \mathrm{E}$ & $\begin{array}{l}\text { Sortilus galloprovincialis } \\
\text { (7) }\end{array}$ \\
\hline
\end{tabular}

Figure 1. Sampling points located in the gulf of La Spezia. The dam was highlighted in red; 1) Portovenere Bay (PB); Palmaria Isle Bay (PALM); 3) East Internal dam (EI); 4) West Internal dam (WI); 5) Central Internal dam (CI); 6) East External dam (EE); 7) West External dam (WE). 
squared analyses. The Mann Whitney U test was finally used also to evaluate the $E$. coli MPN difference between the three group of sampling sites, considering the skewed distribution of data given the asymmetric distribution of the found values.

E. coli MPN of the three-year period 2015-2017 were also compared to those related to the previous three-year period (2012-2014). The comparison was performed both by using aggregated (overall) data with the Mann Whitney U test and considering separately each sampling point by using the Signed rank test. Moreover, considering the putative influence of rainfall on the $E$. coli numbers between the years, a statistical analysis of rainfall differences over time was conducted, by means of paired ttest (group1: 2012/2014-group 2: 2015 2017). Finally, the statistical correlation was performed (using Spearman's rho test) between rainfall and $E$. Coli loads for each year, as to assess differences in significance and magnitude of the effect.
All the statistical analysis was performed by using SPSS vs 12 software for Windows ${ }^{\circledR}$. The results associated to $\mathrm{P}<0.05$ and $\mathrm{P}<0.1$ were considered significant and tending significant, respectively.

\section{Results and Discussion}

\section{Number and type of analysis}

Overall, 4306 analysis were performed. The number and type of the analysed parameters for each species are reported in Table 2. Of them, 2792 (65\%) and 1514 (35\%) were aimed at evaluating MPs and nMPs, respectively. The most part of the analysis ( $\mathrm{n}=1872 ; 44 \%$ of the total analysis) was addressed to the searching and/or quantification of biological agents, of which 1296 bacteriological and 576 virological. Although according to EU legislation the evaluation of LMB safety is based entirely on the use of $E$. coli as an indicator of faecal contamination (Regulation EC n. 854/2004), faecal indicators provide an inadequate index of microbiological safety and are poorly predictive of the presence of other microorganisms such as viruses and pathogenic Vibrio (Marceddu et al., 2017).

This aspect represents a substantial shortcoming, especially considering that the incidence of foodborne outbreaks associated with the consumption of LBM contaminated with such pathogenic micro-organisms is increasing. In 2011, the European Food Safety Authority (EFSA) identified that Norovirus (genogroup GI, GII and GIV) and HAV are the enteric viruses of primary public health concern in relation to LBM (EFSA, 2011). In 2015, CEFAS published a discussion paper to identify options for improving controls for Norovirus and HAV contamination of LBM in EU food legislation (CEFAS, 2015). It was especially recommended that quantitative (maximum acceptable level) and qualitative (presence/absence) standards are introduced

Table 1. MPs and nMPs analysed in the SS-2018 with relative limits.

\begin{tabular}{|c|c|c|c|c|}
\hline Biological agents & $\begin{array}{l}\text { Salmonella spp. } \\
\text { V. cholerae } \\
\text { V. parahaemolyticus and } \\
\text { V. vulnificus } \\
\text { Norovirus } \\
\text { HAV }\end{array}$ & $\begin{array}{l}\text { MP } \\
\text { nMP* } \\
\text { nMP* } \\
\text { nMP* } \\
\text { nMP* }\end{array}$ & $\begin{array}{l}\text { Commission Regulation (EC) n. 2073/2005 } \\
\text { - } \\
\text { - }\end{array}$ & $\begin{array}{l}\text { - Class A: LBMs must not exceed, in } 80 \% \text { of samples } \\
\text { collected during the review period, } 230 \text { E. coli per } \\
100 \mathrm{~g} \text { of flesh and intra-valvular liquid. The remaining } \\
20 \% \text { of samples must not exceed } 700 \text { E. coli } \\
\text { per } 100 \mathrm{~g} \text { of flesh and intra-valvular liquid } \\
\text { - Class B: LBMs must not exceed the limits of a five } \\
\text { tube, three MPN test of } 4600 \mathrm{E} \text {. coli per } 100 \mathrm{~g} \text { of flesh } \\
\text { and intra-valvular liquid. } \\
\text { - Class C: LBMs must not exceed the limits of } \\
\text { a five-tube, three dilution MPN test of } 46000 \mathrm{E} \text {. coli } \\
\text { per } 100 \mathrm{~g} \text { of flesh and intra-valvular liquid. } \\
\text { Absence in } 25 \mathrm{~g} \\
\text { Presence of } V \text {. cholerae } 01 \text { and non-01 } \\
\text { Presence of toxigenic V. parahaemolyticus and V. } \\
\text { vulnificus } \\
\text { Presence/absence } \\
\text { Presence/absence }\end{array}$ \\
\hline Marine biotoxin & $\begin{array}{l}\text { Paralytic Shellfish Poison (PSP) } \\
\text { Amnesic Shellfish Poison (ASP) } \\
\text { Okadaic acid (OA), } \\
\text { dinophysistoxins, pectenotoxins } \\
\text { Yessotoxins } \\
\text { Azaspiracids }\end{array}$ & $\begin{array}{l}\text { MP } \\
\text { MP } \\
\text { MP }\end{array}$ & $\begin{array}{l}\text { Regulation (EC) n. 853/2004 } \\
\text { Regulation (EC) n. 853/2004 } \\
\text { Regulation (EC) n. 853/2004 } \\
\\
\text { Regulation (EC) n. 853/2004 } \\
\text { Regulation (EC) n. 853/2004 }\end{array}$ & $\begin{array}{l}800 \text { micrograms per kilogram } \\
20 \text { milligrams of domoic acid per kilogram } \\
160 \text { micrograms of okadaic acid equivalents } \\
\text { per kilogram } \\
1 \text { milligram of yessotoxin equivalent per kilogram } \\
160 \text { micrograms of azaspiracid equivalents per kilogram }\end{array}$ \\
\hline Chemical agents & $\begin{array}{l}\text { Polycyclic aromatic hydrocarbons (PAH) } \\
\text { Sum of dioxins (WHOPCDD/F-TEQ) } \\
\text { Sum of dioxins and } \\
\text { dioxin-like PCBs } \\
\text { (WHOPCDD/F-PCB-TEQ) } \\
\text { Cadmium (Cd) } \\
\text { Mercury (Hg) } \\
\text { Lead (Pb) } \\
\text { Silver (Ag) } \\
\text { Arsenic (As) } \\
\text { Chromium (Cr) } \\
\text { Nickel (Ni) } \\
\text { Zinc (Zn) }\end{array}$ & $\begin{array}{l}\text { MP } \\
\text { MP } \\
\text { MP } \\
\text { nMP* } \\
\text { nMP* } \\
\text { nMP* } \\
\text { nMP* } \\
\text { nMP* }\end{array}$ & $\begin{array}{l}\text { Regulation (EC) n. 1881/2006 } \\
\text { Regulation (EC) n. 1881/2006 } \\
\text { Regulation (EC) n. 1881/2006 } \\
\text { Legislative Decree n. 152/2006 } \\
\text { Legislative Decree n. 152/2006 } \\
\text { Legislative Decree n. 152/2006 } \\
\text { Legislative Decree n. 152/2006 } \\
\text { Legislative Decree n. 152/2006 }\end{array}$ & $\begin{array}{l}1 \mathrm{mg} / \mathrm{kg} \text { wet weight } \\
0.5 \mathrm{mg} / \mathrm{kg} \text { wet weight } \\
1.5 \mathrm{mg} / \mathrm{kg} \text { wet weight } \\
\mathrm{NR} \\
\mathrm{NR} \\
\mathrm{NR} \\
\mathrm{NR} \\
\mathrm{NR}\end{array}$ \\
\hline Physical agents & Caesium-134 and -137 & MP & Regulation (EC) n. 733/2008 & $600 \mathrm{~Bq} / \mathrm{kg}$ \\
\hline
\end{tabular}


for Norovirus and HAV, respectively (CEFAS, 2015). Furthermore, the necessity to establish criteria for pathogenic viruses and other microbial hazards such as V. parahaemolyticus in LBM has been already expressed in the Commission Regulation (EC) n. 2073/2005 on microbiological criteria for foodstuffs. To date, although it's been fourteen, limits neither for pathogenic virus nor for Vibrio spp. have been fixed. For this reason, in many EU countries, including Italy, production control plans have been implemented according to the dispositions of the CEFAS guidelines. In addition, the Italian Ministry of Health issued different documents, among which the following are particularly of concern: the Ministry of Health Circular letter with reference DVGA-III.IX/32799/P-I/11, $15 / 09 / 2005$, establishing that to ascertain the non-conformity of a product, isolates ascribed to the species $V$. parahaemolyticus must be characterized to the molecular level, with respect to the presence of the pathogenic genes tdh and/or trh; the Ministry of Health Communication with reference Prot. Uff. III ex DGVA/35312, $5 / 10 / 2006$, reporting the Opinion of the Superior Institute of Health on the identifi- cation of the toxic factors related to $V$. cholerae non-O1/non-O139 (presence of the gene target $\mathrm{stn} / \mathrm{sto}), V$. alginolyticus (neither molecular characterization nor limit) and V. vulnificus (that must be $<103$ CFU g-1).

Carrying on with the count, 1785 analysis $(41 \%)$ were addressed to the searching of marine biotoxin. In this case, the sampling was performed with greater frequency during the spring-summer periods, due to the higher risk related to the algal blooms (Berdalet et al. 2016). Finally, 604 (14\%) and $45(1 \%)$ analysis were addressed to the searching of chemical agents and radionuclides, respectively (Table 2). Of the whole, M. galloprovincialis was the most analysed species $(\mathrm{n}=3843 ; 89 \%)$ followed by $C$. gigas $(\mathrm{n}=225 ; 6 \%)$ and $V$. verrucosa $(\mathrm{n}=208 ; 5 \%)$. This aspect was firstly related to the major number of sampling points (Figure 1); moreover, the biotoxin were analysed only in $M$. galloprovincialis (Table 2) selected as biotoxin indicator according to the State-Region Conference implementing the Regulations EC $n$. $853 / 2004$ and 854/2004. Furthermore, Norovirus, HAV and radionuclides were not analysed at all in the species $V$. verrucosa due to issues in samples retrieval from the natural beds.

\section{NC evaluation}

Overall, $160 \mathrm{NC}$ were detected, and they were related to biological agents $(E$. coli, Salmonella spp. and Norovirus) and biotoxin (DA and OA) (Table 3). By analysing the outcomes of the SS-2018, the necessity to include the virological analysis was undoubtedly proved. In fact, NC related to the presence of Norovirus were the most detected $(n=150)$, representing the $93.7 \%$ of the total $\mathrm{NC}$ and the most part were found in M. galloprovincialis $(\mathrm{n}=134$; $89.3 \%$ ) (Table 3). An average Norovirus prevalence of $53.2 \%$ was found in this species; by separately evaluating each sampling points, WI, PB and PALM presented a higher virus prevalence $(61.1 \%, 58.3 \%$ and $58.3 \%$, respectively) respect to $\mathrm{EI}, \mathrm{CI}, \mathrm{EE}$ and WE $(55.5 \%, 50 \%, 47.2 \%$ and $40.6 \%$, respectively). Although the different Norovirus prevalence among the sampling points (section 3.2), no significative difference was revealed by the statistical analysis. The Norovirus genogroup GII was found in $22.2 \%$ of the positive samples and GI in $3.5 \%$, while both the genogroups were found in the remained $20.8 \%$. Overall, with

Table 2. Number and type of analysis performed in SS-2018. SP: number of sampling points.

\begin{tabular}{|c|c|c|c|c|c|}
\hline & & vincialis $(\mathrm{SP}=7)$ & C. gigas $(\mathrm{SP}=1)$ & V. verrucosa $(\mathrm{SP}=2)$ & Total \\
\hline Biological agents & $\begin{array}{l}\text { E. coli } \\
\text { Salmonella spp. } \\
\text { V. cholerae } \\
\text { V. parahaemoliticus } \\
\text { Norovirus } \\
\text { HAV } \\
\text { Subtotal }\end{array}$ & $\begin{array}{l}252 \\
252 \\
252 \\
252 \\
252 \\
252 \\
1512\end{array}$ & $\begin{array}{c}36 \\
36 \\
36 \\
36 \\
36 \\
36 \\
216\end{array}$ & $\begin{array}{c}36 \\
36 \\
36 \\
36 \\
- \\
- \\
144\end{array}$ & $\begin{array}{r}324 \\
324 \\
324 \\
324 \\
288 \\
288 \\
1872\end{array}$ \\
\hline Biotoxin & $\begin{array}{l}\text { Paralytic Shellfish Poison (PSP) } \\
\text { Domoic acid (DA) } \\
\text { Okadaic acid (OA) } \\
\text { Yessotoxins } \\
\text { Azaspiracids } \\
\text { Subtotal }\end{array}$ & $\begin{array}{c}357 \\
357 \\
357 \\
357 \\
357 \\
1785\end{array}$ & $\begin{array}{l}- \\
- \\
- \\
- \\
-\end{array}$ & $\begin{array}{l}- \\
- \\
- \\
- \\
- \\
-\end{array}$ & $\begin{array}{c}357 \\
357 \\
357 \\
357 \\
357 \\
1785\end{array}$ \\
\hline Chemical agents & $\begin{array}{l}\text { Polycyclic aromatic hydrocarbons (PAH) } \\
\text { Sum of dioxins (WHOPCDD/F-TEQ) } \\
\text { Sum of dioxins and } \\
\text { dioxin-like PCBs (WHOPCDD/F-PCB-TEQ) } \\
\text { PCB markers } \\
\text { Cadmium (Cd) } \\
\text { Mercury (Hg) } \\
\text { Lead (Pb) } \\
\text { Silver (Ag) } \\
\text { Arsenic (As) } \\
\text { Chromium (Cr) } \\
\text { Nickel (Ni) } \\
\text { Zinc (Zn) } \\
\text { Subtotal }\end{array}$ & $\begin{array}{l}42 \\
42 \\
42 \\
42 \\
42 \\
42 \\
42 \\
42 \\
42 \\
42 \\
42 \\
42 \\
504\end{array}$ & $\begin{array}{l}3 \\
3 \\
3 \\
\\
3 \\
3 \\
3 \\
3 \\
3 \\
3 \\
3 \\
3 \\
3 \\
36\end{array}$ & $\begin{array}{l}6 \\
6 \\
6 \\
6 \\
6 \\
6 \\
8 \\
6 \\
4 \\
4 \\
4 \\
4 \\
4 \\
64\end{array}$ & $\begin{array}{l}51 \\
51 \\
51 \\
51 \\
51 \\
53 \\
51 \\
49 \\
49 \\
49 \\
49 \\
49 \\
604\end{array}$ \\
\hline Physical agents & $\begin{array}{l}\text { Caesium-134 and - } 137 \\
\text { Subtotal }\end{array}$ & $\begin{array}{l}42 \\
42\end{array}$ & $\begin{array}{l}3 \\
3\end{array}$ & - & $\begin{array}{l}45 \\
45\end{array}$ \\
\hline Total & & 3843 & 255 & 208 & 4306 \\
\hline
\end{tabular}


a prevalence of $92.5 \%$, GII was the most representative in this species. The observed prevalence In $M$. galloprovincialis stood among the highest within the Italian context. Similar scenario was reported only in an investigation on the three-year period 2007-2010 in Campania, with a prevalence of 57.7\% (Pepe et al. 2012) and in 2014 in Sardinia and Veneto, with a prevalence of $52 \%$ and $51.4 \%$, respectively (Suffredini et al. 2014a), while all the other investigations performed over the past few years highlighted lower prevalence (Fusco et al. 2017; La Bella et al. 2014; Bazzardi et al. 2014; Fusco et al. 2013). Even the higher prevalence of the genogroup GII was in accordance with most of the outcomes of other national surveys (Fusco et al. 2017; La Bella et al. 2017; Marceddu et al. 2017; Bazzardi et al. 2014; Suffredini et al. 2014a; Fusco et al. 2013; Pepe et al 2012). In light of above, it is evident that proper management measures should be applied in the examined production areas for avoiding an eventual downgrading whereas the virological analysis are included in the future.

The presence of Norovirus was the unique type of $\mathrm{NC}$ found in the species $C$. gigas (Table 3 ). With a prevalence of $2.7 \%$, $13.8 \%$ and $27.7 \%$ for GI, GII and GI+GII genogroup, respectively, GII was the most representative also in this species (94\%).

The level of $E$. coli and biotoxin was found as non-compliant in $5(3.1 \%$ of the total $\mathrm{NC})$ and $4(2.5 \%$ of the total $\mathrm{NC})$ cases, respectively, while Salmonella spp. was detected in only 1 case $(0.6 \%$ of the total NC). All the NC for the MPs E. coli and biotoxin were found in the species $M$. galloprovincialis. NC for the parameter $E$. coli covered a percentage of about $2 \%$ respect to the number of analysis performed on this species $(\mathrm{n}=252)$ (Table 2$)$. The limit of $4600 \mathrm{E}$. coli MPN/100g was exceeded in the analysis of five sampling from five different sampling points during the three-year period; in detail, the higher value (18000 MPN/100g) was detected in a sampling performed in July 2015 from WE; values of $17000 \mathrm{MPN} / 100 \mathrm{~g}, 13000 \mathrm{MPN} / 100 \mathrm{~g}$ and $7000 \mathrm{MPN} / 100 \mathrm{~g}$ were detected in three

Table 3. Number and type of NC found in SS-2018.

\begin{tabular}{llcc} 
& & Species & NC (n) \\
Biological agents & E. coli & M. galloprovincialis & 5 \\
& Salmonella spp. & V. verrucosa & 1 \\
& Norovirus & M. galloprovincialis & 134 \\
& & C. gigas & 16 \\
Biotoxin & DA & M. galloprovincialis & 2 \\
& OA & M.galloprovincialis & 2 \\
\hline Total & & & 160 \\
\hline
\end{tabular}

lighted a significant difference between the groups "inside the dam"-"Portovenere Bay/Palmaria Isle Bay" and the group "outside the dam", with significantly higher MPN values $(\mathrm{P}=0.021)$ in the first case. This aspect could be related to the fact that the sea current is slower in the sampling points located inside the dam and within Portovenere Bay/Palmaria Isle Bay due to the barrier role played by the dam itself. This hypothesis was already made by the SS-2018. Finally, the correlation between MPN values and rainfall on data from 2012 to 2017 was proved as significant in MPN measured both at $4(\mathrm{Rho}=0.23 ; \mathrm{P}<0.001)$ and 7 days before the sampling $(\mathrm{Rho}=0.27$; $\mathrm{P}<0.001$ ).

As regards biotoxin, the 2 reported $\mathrm{NC}$ for $\mathrm{OA}$ were detected in sampling from PALM and EE in September 2015 and the 2 $\mathrm{NC}$ for DA in sampling from EI and EE in May 2016. With concentrations of 25.8 $\mathrm{mg} / \mathrm{kg}$ (PALM) and $21.9 \mathrm{mg} / \mathrm{kg}$ (EE) for $\mathrm{OA}$ and $165.8 \mu \mathrm{g} / \mathrm{kg}(\mathrm{EI})$ and $162.6 \mu \mathrm{g} / \mathrm{kg}$ (EE) for DA, the EU limit was slightly exceeded (Regulation EC n. 853/2004). The unique NC related to the presence of Salmonella spp. was detected in $V$. verrucosa (Table 3). In this regard, no cases of contamination with Salmonella spp. in truffles are reported in literature.

$\mathrm{NC}$ related to the presence of Vibrio spp. and HAV were not detected. This aspect is relevant if compared with the national scene, where cases of $\mathrm{NC}$ for these pathogens were occurred in the last years (Marceddu et al., 2017; Costantino et al., 2017; Suffredini et al., 2017; Serratore et al., 2016; Iaconelli et al., 2015; Suffredini et al., 2014b).

In the same way, no $\mathrm{NC}$ related to chemical and physical agents were detected in all the three-year period. Also in this case, these outcomes were sometimes not in accordance with other national realities, where the chemicals levels were found as non-compliant with the limits fixed by the legislation (Arienzo et al., 2019; Ferrante et al., 2018; Esposito et al., 2017).

Given these conditions, the collection of new data from different investigation areas could be nationally useful for modifying the monitoring plans on a seasonal basis, according to the risk assessment.

\section{Production areas re-classification}

At the end of the sanitary survey 20152017 the production areas were confirmed as B for $M$. galloprovincialis. In fact, although cases of $\mathrm{NC}$ for $E$. coli were found (section 3.2) the tolerance of $10 \%$ of the microbiological results above 4,600 MPN E. coli/100g of flesh and intra-valvular liquid for Class B (Regulation EC n. 
854/2004) (Table 1) was respected. By comparing the E. coli MPN of the threeyear period 2015-2017 to those related to the previous three-year period (2012-2014), no significant differences were observed neither aggregated nor non-aggregated data.

Contrariwise, the $C$. gigas production areas were re-classified as A given their observed better health status respect to the previous three-years period. Finally, as the sampling of $V$. verrucosa was insufficient for a proper re-classification, all the natural beds were closed.

\section{Conclusions}

With the sanitary survey performed during the three-years period 2015-2017 the production areas of the gulf of La Spezia were re-classified. The reclassification has been achieved by means of reliable data obtained by a proper and strategic sampling plan, except in the case of $V$. verrucosa harvest areas, that have been consequently closed. The analysis of parameters fixed by both EU dispositions and local monitoring plan allowed to well monitor the major risks related to LBM production areas of the gulf of La Spezia. Given the observed prevalence of Norovirus, the possibility to include pathogenic viruses in the list of mandatory parameters should be considered. Moreover, the impact of both seasonality and rainfall on the faecal contamination was proved by the statistical analysis. Therefore, the sanitary survey introduced by the Regulation EC n. 854/2004 was proved an essential tool to over time monitor the sanitary status of the LBM production areas and to provide useful data for the official monitoring plan up-dating.

\section{References}

Almeida C, Soares F, 2012. Microbiological monitoring of bivalves from the Ria Formosa Lagoon (south coast of Portugal): A 20 years of sanitary survey. Mar Pollut Bull 64:252-62.

Arienzo M, Toscanesi M, Trifuoggi M, Ferrara L, Stanislao C, Donadio C, Carella F, 2019. Contaminants bioaccumulation and pathological assessment in Mytilus galloprovincialis in coastal waters facing the brownfield site of Bagnoli, Italy. Mar Pollut Bull 140:34152.

As15 Spezzino, 2018. Piano di monitoraggio e sorveglianza dei molluschi bivalvi 2018: produzione, depurazione, commercializzazione secondo le linee guida
Comunitarie.

Bazzardi R, Fattaccio MC, Salza S, Canu A, Marongiu E, Pisanu M, 2014. Preliminary study on Norovirus, hepatitis A virus, Escherichia coli and their potential seasonality in shellfish from different growing and harvesting areas in Sardinia region. Ital $\mathrm{J}$ Food Saf 3:1601.

Berdalet E, Fleming LE, Gowen R, Davidson K, Hess $\mathrm{P}$, Backer LC, Enevoldsen H, 2016. Marine harmful algal blooms, human health and wellbeing: challenges and opportunities in the 21 st century. J Mar Biol Assoc UK 96:61-91.

Campos CJ, Kershaw S, Lee RJ, Morgan OC, Hargin K, 2011. Rainfall and river flows are predictors for $\beta$-glucuronidase positive Escherichia coli accumulation in mussels and Pacific oysters from the Dart Estuary (England). J Water Health 9:368-81.

CEFAS, 2015. Discussion paper on Live Bivalve Molluscs (LBM) and human enteric virus contamination: options for improving risk management in EU food hygiene package. https://eurlcefas.org/media/13637/ws12 15.pdf

CEFAS, 2017. Microbiological monitoring of bivalve mollusc harvesting areas guide to good practice: technical application. EU Working Group on the microbiological monitoring of bivalve mollusc harvesting areas, Issue 6 : January 2017.

Commission Regulation (EC) n. 2073/2005 of 15 November 2005 on microbiological criteria for foodstuffs. OJ 50:1-26.

Commission Regulation (EC) n. 1881/2006 of 19 December 2006 setting maximum levels for certain contaminants in foodstuffs. OJ 364:365-324.

Costantino A, Coppola N, Spada E, Bruni R, Taffon S, Equestre M, Mascolo S, 2017. Hepatitis A virus strains circulating during 1997 $\square 2015$ in Campania, a Southern Italy region with periodic outbreaks. J Med Virol 89:1931-6.

Council Regulation (EC) n. 733/2008 of 15 July 2008 on the conditions governing imports of agricultural products originating in third countries following the accident at the Chernobyl nuclear power station. OJ L201:1-7.

EFSA 2011. Scientific Opinion on an update on the present knowledge on the occurrence and control of foodborne viruses. EFSA J 9.

EFSA, 2015. Evaluation of heat treatments, different from those currently established in the EU legislation, that could be applied to live bivalve molluscs from
$\mathrm{B}$ and $\mathrm{C}$ production areas, that have not been submitted to purification or relaying, in order to eliminate pathogenic microorganisms. EFSA J 13.

Esposito M, Perugini M, Lambiase S, Conte A, Baldi L, Amorena M, 2017. Seasonal trend of PAHs concentrations in farmed mussels from the coastal areas of the Naples, Italy. B Environ Contam Tox 99:333-7.

European Commission's Food and Veterinary Office, 2014. Overview report on audits in Member States in order to evaluate the official control systems in place for production and placing on the market of bivalve molluscs. Directorate for Health and Food Audits and Analysis, 2014.

Ferrante M, Zanghì G, Cristaldi A, Copat C, Grasso A, Fiore M, Conti GO, 2018. PAHs in seafood from the Mediterranean Sea: an exposure risk assessment. Food Chem Toxicol 115:385-90.

Fusco G, Aprea G, Galiero G, Guarino A, Viscardi M, 2013. Escherichia coli, Salmonella spp., Hepatitis A Virus and Norovirus in bivalve molluses in Southern Italy. Vet Ital 49:55-58.

Fusco G, Di Bartolo I, Cioffi B, Ianiro G, Palermo P, Monini M, Amoroso MG, 2017. Prevalence of foodborne viruses in mussels in Southern Italy. Food Environ Virol 9:187-94.

Iaconelli M, Purpari G, Della Libera S, Petricca S, Guercio A, Ciccaglione AR, Muscillo M, 2015. Hepatitis A and E viruses in wastewaters, in river waters, and in bivalve molluscs in Italy. Food Environ Virol 7:316-24.

La Bella G, Martella V, Basanisi MG, Nobili G, Terio V, La Salandra G, 2017. Food-borne viruses in shellfish: investigation on norovirus and HAV presence in Apulia (SE Italy). Food Environ Virol 9:179-86.

Marceddu M, Lamon S, Consolati S, Ciulli S, Mazza R, Mureddu A, Meloni D, 2017. Determination of Salmonella spp., E. coli VTEC, Vibrio spp., and Norovirus GI-GII in bivalve molluscs collected from growing natural beds in Sardinia (Italy). Foods 6:88.

Pepe T, Ventrone I, Suffredini E, Ceruso M, Croci L, Anastasio A, Cortesi ML, 2012. Norovirus monitoring in bivalve molluscs harvested and commercialized in southern Italy. J Food Protect 75:97681.

Potasman I, Paz A, Odeh M, 2002. Infectious outbreaks associated with bivalve shellfish consumption: a worldwide perspective. Clin Infect Dis 35:921-928. 
Regulation (EC) n. 853/2004 of the European Parliament and of the Council of 29 April 2004 laying down specific rules for food of animal origin. OJ L226:22-82.

Regulation (EC) n. 854/2004 of the European Parliament and of the Council of 29 April 2004 laying down specific rules for the organisation of official controls on products of animal origin intended for human consumption. OJ L226:83-127.

Sanitary Survey, 2015. Riclassificazione delle acque del Golfo della Spezia ai fini della molluschicoltura ai sensi del Reg CE n. 854/2004. Asl 5 Liguria Dipartimento di Prevenzione S.C. Igiene degli Alimenti di Origine Animale

Sanitary Survey, 2018. Riclassificazione delle zone del Golfo della Spezia adibite alla molluschicoltura. Asl 5 Liguria Dipartimento di Prevenzione S.C. Igiene degli Alimenti di Origine Animale

Serratore P, Ostanello F, Passalacqua PL, Zavatta E, Bignami G, Serraino A, Giacometti F, 2016. First multi-year retrospective study on Vibrio Parhaemolyticus and Vibrio Vulnificus prevalence in Ruditapes Philippinarum harvested in Sacca di Goro, Italy. Ital J Food Saf 5:6161.

Suffredini E, Lanni L, Arcangeli G, Pepe T, Mazzette R, Ciccaglioni G, Croci L, 2014a. Qualitative and quantitative assessment of viral contamination in bivalve molluscs harvested in Italy. Int J Food Microbiol 184:21-6.

Suffredini E, Mioni R, Mazzette R, Bordin
P, Serratore P, Fois F, Croci L, 2014b. Detection and quantification of Vibrio parahaemolyticus in shellfish from Italian production areas. Int $\mathrm{J}$ Food Miocrobiol 184:14-20.

Suffredini E, Proroga YTR, Di Pasquale S, Di Maro O, Losardo M, Cozzi L, De Medici D, 2017. Occurrence and trend of hepatitis a virus in bivalve molluscs production areas following a contamination event. Food Environ Virol 9:42333.

Tabanelli G, Montanari C, Gardini A, Maffei M, Prioli C, Gardini F, 2017. Environmental factors affecting Escherichia coli concentrations in striped Venus clam (Chamelea gallina L.) harvested in the North Adriatic Sea. J Food Protect 80:1429-35. 